\title{
A márkaelkerülés motivációi
}

\author{
Tamasits Dóra \\ Szegedi Tudományegyetem
}

\section{A TANULMÁNY CÉLJA}

Jelen tanulmány a széles körben ismert és vitatott fogyasztó-márka viszonyt mutatja be, különösen a márkaelkerülésre koncentrálva. A negatív fogyasztó-márka közötti viszony vizsgálata aktualitásnak tekinthető, habár jellemzően a fogyasztói magatartás kutatásokban a fogyasztói lojalitás kerül a vizsgálatok középpontjába, míg a márkaelkerülés szakirodalma viszonylag szükösnek mondható.

\section{ALKALMAZOTT MÓDSZERTAN}

A kutatási kérdések megválaszolására egy primer kutatás szolgál. A kutatás során három mélyinterjú és kettő fókuszcsoportos kutatás került lebonyolításra 2018 őszén a márkaelkerülés motivációinak feltárása érdekében.

\section{LEGFONTOSABB EREDMÉNYEK}

Előzetes feltételezések alapján az önkifejező (szimbolikus) fogyasztás lehet meghatározó tényező a márkaelkerülésnél, azaz a fogyasztó a márkát a márkaszemélyiség, illetve a tipikus használójáról kialakult kép miatt utasítja el. A kvalitatív kutatás eredményei részben alátámasztják ezt az előzetes feltételezést, azonban a márkaelkerülés során a funkcionális tényezők és a reklámok üzenetei is fontos tényezőnek bizonyultak.

\section{GYAKORLATI JAVASLATOK}

Annak feltárása, hogy milyen tényezők játszanak szerepet a márkaelkerülés során kiemelt jelentőséggel bír, hiszen egyrészről, ha ismerjük a márkaelkerülés okait megelőzhetővé válik további fogyasztók elvesztése, másrészről egy márka sikerénél a fogyasztók véleménye meghatározó, hiszen a negatív szájreklám káros lehet.

Kulcsszavak: fogyasztó-márka viszony, márkaelkerülés, fogyasztás ellenesség

DOI: 10.15170/MM.2020.54.KSZ.III.07 


\section{BEVEZETÉS INTRODUCTION}

Számos kutatás foglalkozik a márkahüség szimbolikus jellegével, igazolva, hogy a fogyasztók gyakran ragaszkodnak olyan márkákhoz, amelyekkel kifejezhetik személyiségüket és pozitív előnyökhöz jutnak a márkák által (Aaker 1997, Belk 1988, Levy 1956, Sirgy 1982). Kevés kutatás foglalkozik azonban azoknak a motivációknak a feltárásával, hogy a fogyasztók miért térnek át egyik márkáról a másikra, illetve miért kerülnek el bizonyos márkákat vagy termékeket. Annak a feltárása, hogy miért alakul ki ellenérzés az egyénben a márkával szemben szintén fontos, hiszen, ha ismerjük a márkaelkerülés okait megelőzhetővé válik további fogyasztók elvesztése. Továbbá a negatív szájreklám megelőzése, illetve hatékony kezelése kulcsfontosságú lehet egy márka sikerességénél. Fontos azoknak a tapasztalatoknak és motivációknak a feltárása, hogy mi okozza a negatív irányú attitüdöt az egyénben a márka iránt. Ezek ismeretében a későbbiekben megoldást találhatunk arra, hogy kedvezőbb irányba mozdítsuk el a márkával kapcsolatos ellenérzéseket.

Jelen tanulmány tágabb értelemben vett célja, a fogyasztó és a márka közötti kapcsolat vizsgálata, mellyel ugyan elméleti és gyakorlati szinten egyaránt sokat foglalkoznak napjainkban, de még mindig hiányzik a kellően letisztult keretrendszer. A különböző tipizálások és módszerek erdejében gyakran nehezen igazodnak el a kutatók, és még inkább a gyakorlati szakemberek. Ez lehet a magyarázata annak, hogy hazánkban a fogyasztó-márka viszony mind elméleti, de különösen gyakorlati szinten kevéssé ismert, alkalmazott megközelítés. A tanulmány szükebb értelemben vett célja, hogy a fogyasztó-márka közötti kapcsolatok közül a negatív irányú kapcsolatot mélyebben megvizsgálja, melynek szakirodalma különösen szükösnek számít. A tanulmány a szakirodalmi áttekintés mellett feltáró kutatást is tartalmaz, amellyel a negatív irányú fogyasztó-márka kapcsolat mozgatórugóira kíván rávilágítani. A primer kutatás célja, azoknak az okoknak a feltárása, amelyek a márkaelkerülésben szerepet játszhatnak, abban az esetben, ha a fogyasztó számára adott a pénzügyi háttér egy bizonyos márka megvásárlásához, a fogyasztó számára elérhető és hozzáférhető a márka, de mégis tudatosan úgy dönt, hogy elkerül egy adott márkát, és egy (vagy akár bármely) versenytársát vásárolja.

\section{AZ ANTIFOGYASZTÁS, MINT A MÁRKAELKERÜLÉS ELMÉ- LETI HÁTTERE ANTI-CONSUMPTION AS THE THEORETICAL BACKGROUND OF BRAND AVOIDANCE}

A negatív fogyasztó-márka kapcsolat szakirodalma igen szükösnek tekinthető, ezért jellemzően az anti-fogyasztás (anti-consumption) témakör keretein belül tárgyalják ezt a jelenséget. A negatív fogyasztó-márka kapcsolat esetében az anti-fogyasztás területéröl különösen azok a kutatások fontosak, amelyek érintik a vásárlói elégedetlenséget, a fogyasztói ellenállást továbbá az énkép-illeszkedést (Lee et al. 2009a, Lee et al. 2009b, Iyer \& Muncy 2009). Az anti-fogyasztás vizsgálatok során azt próbálják feltárni, hogy a fogyasztók miért nem vásárolnak meg bizonyos márkákat vagy adott esetben miért csökkentik a vásárlásaikat egy bizonyos márkára vonatkozóan. Az anti-fogyasztás területén az egyik legfontosabb eredmény az anti-fogyasztók tipizálása, amely Iyer és Muncy (2009) nevéhez füződik. A szerzőpáros a fogyasztók négy típusát különböztette meg a fogyasztásuk csökkentésének tárgya és célja szerint. Ezek alapján a fogyasztás-ellenes fogyasztói csoportokat a 1. táblázat mutatja be.

1. táblázat: Az antifogyasztók négy típusa

Table 1. Four categories of anti-consumption

\begin{tabular}{|l|l|l|l|}
\hline \multicolumn{2}{|c|}{} & \multicolumn{2}{c|}{ Anti-fogyasztás célja } \\
\cline { 3 - 4 } & Társadalmi vonatkozás & Személyes vonatkozás \\
\hline \multirow{2}{*}{ Anti-fogyasztás tárgya } & Általános & Globális problémák elleni törekvés & Önkéntes egyszerüsítök \\
\cline { 2 - 4 } & Specifikus & Piaci aktivisták & Anti-lojális fogyasztók \\
\hline
\end{tabular}

Forrás: Iyer \& Muncy 2009161 alapján 
A táblázatból jól látható, hogy vannak olyan fogyasztók, akik általában véve minden termékre kiterjedően csökkentik vagy szüntetik meg a fogyasztásukat, míg vannak olyan fogyasztók, akik csak néhány márka vonatkozásában teszik ezt. Továbbá fontos differenciáló tényező, hogy az egyének a társadalmi és környezeti kérdéseket tartják-e inkább fontosnak (fenntarthatóság) vagy inkább személyes vonatkozása van a fogyasztásuk csökkentésének esetleg megszüntetésének. Az anti-fogyasztók egyik csoportja a globális problémák ellen aktívan fellépők csoportja. Véleményük szerint a fogyasztói társadalom és a fogyasztás jelenlegi mértéke kedvezötlen hatással van a környezetre. A túlfogyasztás számos problémát okoz, illetve helyrehozhatatlan károkat okoznak a Föld ökoszisztémájában. Annak érdekében, hogy felhívják a figyelmet korunk túlzott fogyasztásának a negatív hatásaira, illetve arra, hogy a túlfogyasztás hogyan befolyásolja a társadalmunkat és a környezetünket egy kezdeményezés alakult „Buy Nothing Day" néven, amely a Black Friday ellentéteként fogható fel. A második csoportja a vásárlás ellenes fogyasztóknak az „önkéntes egyszerüsítők” csoportja (Holt 1998). A fogyasztók ezen csoportja felhagy a fogyasztói társadalmi életformával és egy egyszerübb, kevésbé fogyasztás orientált életstílust választanak. Úgy gondolják, hogy a fogyasztói társadalom negatív hatása a stressz, kimerültség és a kiábrándulás, így a fogyasztás orientált életformától való elfordulás elsősorban egy belső elkötelezödésen alapul. A piaci aktivisták egy bizonyos márkát kerülnek el, mert véleményük szerint a márka vagy a vállalat társadalmi problémákat okoz. A piaci aktivistákat számos média támogatja abban, hogy a negatív hatásokkal kapcsolatos információk széles körben elterjedjenek. Végül, az anti-lojális fogyasztók csoportjába azok az egyének tartoznak, akik szándékosan nem vásárolják meg az adott márkát mert, úgy gondolják, hogy a márka „alkalmatlan”, illetve negatív tapasztalataik vannak a márkával kapcsolatban (Iyer \& Muncy 2009). Az anti-fogyasztók tipizálásából jól látható, hogy a márkaelkerülés vizsgálata multidimenzionális jelleget ölt, ebböl kifolyólag érdemes széles perspektívából megközelíteni a jelenség vizsgálatát, azonban jelen tanulmány szempontjából az antifogyasztók csoportjai közül, az anti-lojális fogyasztók csoportja a releváns, hiszen a primer kutatásom során egy adott márka vonatkozásában vizsgáltam a márkaelkerülés motivációt.

\section{A MÁRKAELKERÜLÉS MOTIVÁCIÓI MOTIVATIONS OF BRAND AVOIDANCE}

A márkaelkerülésnek (brand avoidance) nincs általánosan elfogadott definíciója, jellemzően viselkedés mintákat és motivációkat próbálnak feltárni a jelenség mögött (Hogg 1998, Lee et al. 2009, White et al. 2012). A márkaelkerülés jelenségét Lee és szerzőtársai (2009) úgy fogalmazzák meg, mint olyan esetek, amikor a fogyasztók szándékosan választják azt, hogy visszautasítják egy márka megvásárlását. A fogalom azt sugallja, hogy a fogyasztónak megvan a pénzügyi lehetősége arra, hogy megvásárolja a márkát, valamint fizikailag elérhető számára a márka, de mégsem vásárolja meg. Lee és szerzőtársai (2009a) egy feltáró kutatásuk során négy fő kategóriába sorolták azokat a motívumokat, amelyek központi szerepet tölthetnek be a márkaelkerülés során. A későbbiekben Knittel et al. (2012) szintén egy feltáró kutatás eredményeként egy ötödik kategóriát is meghatározott. A márkaelkerülés motivációit az 1. ábra mutatja be. 


\section{1. ábra: A márkaelkerülés motivációi \\ Figure 1. Motivations of brand avoidance}

\begin{tabular}{|c|c|}
\hline $\begin{array}{l}\text { Tapasztalaton } \\
\text { alapuló } \\
\text { elkerülés }\end{array}$ & $\begin{array}{l}\text { Önkifejezés } \\
\text { miatti elkerülés }\end{array}$ \\
\hline $\begin{array}{l}\text { - Gyenge } \\
\text { teljesítmény } \\
\text { - Kellemetlen- } \\
\text { ségek } \\
\text { - Áruházi/bolti } \\
\text { környezet }\end{array}$ & $\begin{array}{l}\text { - Negatív } \\
\text { referencia- } \\
\text { csoport } \\
\text { - Hiteltelenség } \\
\text { - Az } \\
\text { individualizáció } \\
\text { elvesztése }\end{array}$ \\
\hline
\end{tabular}
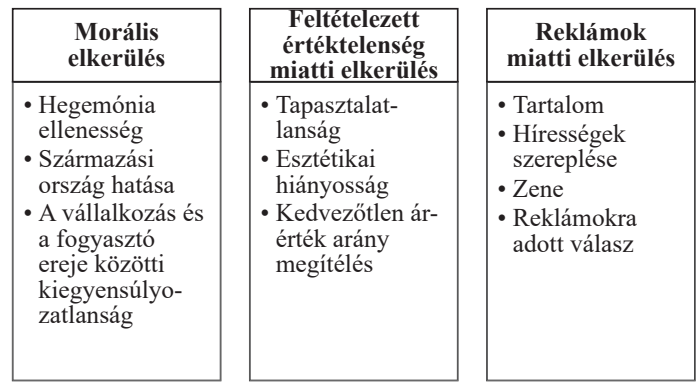

Forrás: Lee et al. (2009a), Lee et al. (2009b), Knittel et al. (2016), Nenycz-Thiel \& Romaniuk (2011,) White et al. (2012) alapján

A tapasztalaton alapuló márkaelkerülés (experiential avoidance), amely a termék használatából eredő negatív tapasztalatokat, az ebből adódó a márkával való elégedetlenséget jelenti. A tapasztalaton alapuló márkaelkerülés a márkaígéret és a fogyasztói elvárások különbségéböl adódik. A fogyasztó összehasonlítja az általa elvárt, kívánt termék teljesítményt a termék valódi teljesítményével, és ha a fogyasztói elvárások nem egyeznek meg a márka által nyújtott teljesítménnyel, elégedetlenséghez, valamint márkaelkerüléshez vezethet (Lee et al. 2009a, Szántó 2003). Az elégedetlenség magában foglalja egy-egy márka teljesítményével, illetve a vásárlás környezetével való elégedetlenséget.

Az önkifejezés miatti márkaelkerülés (identity avoidance) azokat a tényezőket foglalja magában, amelyek a márkák szimbolikus jelentéstartalmával illetve az énkép-illeszkedéssel függenek össze. A márkák által sugallt kép nagymértékben befolyásolja azt, hogy melyik márkát választják egy-egy vásárlás alkalmával a fogyasztók, ugyanis a márkához társított személyiségjegyek és szimbolikus tartalmak alapján tudnak a fogyasztók azonosulni a márkával. Az egyén identitása és a márka által sugallt kép közötti egyezőséget a szakirodalom (Sirgy 1982, Kressman et al. 2006, Grzeskowiak \& Sirgy 2007, Gyulavári - Malota 2014) énképilleszkedésnek hívja, mely arra a jelenségre utal, amikor a fogyasztó döntését jelentősen befolyásolja, hogy mennyiben illeszkedik a termék imázsa a fogyasztó énképéhez. Grubb és Grathwohl (1967) megállapította, hogy az énkoncepció értékkel bír az egyén számára, és viselkedése, fogyasztói magatartása annak védelmére, valamint az énkon- cepció hangsúlyozására irányul. Amennyiben a márka által sugallt kép és az egyén identitása között ellentét áll fent a márkaelkerülés valószínüsége fennáll, hiszen az elutasítás motivációja mögött egy nem kívánt énkép elutasítása áll. Az önkifejezésen alapuló márkaelkerülés magában foglalja a negatív referencia csoportokat, a hiteltelenséget és a deindividualizációt. A negatív referencia csoport egy olyan csoportot jelöl, ahova az egyén nem szeretne tartozni, amelyet elutasít, illetve amelynek értékrendjével nem ért egyet (Lee et al. 2009b). White et al. (2012) feltáró kutatásának eredményei szintén kimutatták a márkaelutasítás motivációi között a márka tipikus használójától való különbözőséget. Megállapításaik szerint a márkaelutasítás egyrészt az „én” védelmének érdekében történik, másrészt a társadalmi énkép megörzése a cél, amelyre vonatkozóan mások véleménye domináns lehet. A White et al. (2012) által megállapított társadalmi énkép (social self-concept) megörzése céljából történő márkaelkerülés egyik motivációja lehet, hogy bizonyos márka használatával a fogyasztók nem szeretnék azt kommunikálni a társaik felé, hogy alacsonyabb társadalmi osztályba tartoznak, így inkább elkerülik azokat. Ebben az esetben fontos megjegyezni, hogy lehetnek olyan márkák, amelyek a fogyasztó számára megfelelőek arra, hogy otthon használja öket (ahol mások nem láthatják), de ahhoz nem elég jók, hogy mások számára láthatóvá tegye a márka használatot. Ez az észlelt nyilvános visszacsatolás - mások véleménye vagy reakciója - különbözteti meg azokat a fogyasztókat, akik a társadalmi énképük védelme miatt kerülnek el egy bizonyos márkát azoktól, akik viszont a „belső én” védelme miatt kerülnek egy adott márkát (White $e t$ 
al. 2012). Mindezeken túl vannak fogyasztók, akik az egyéniségük hangsúlyozása érdekében utasítanak vissza bizonyos márkákat, ugyanis fogyasztásukkal nem szeretnének a divatot követők közé tartozni. Elutasítanak bizonyos márkákat, mert ők szeretnének elkülönülni a többi - tömegízlést követő - fogyasztótól (Kovács 2009). Az előző gondolatmenet alapján látható tehát, hogy a társas interakciók szerepe releváns szempont a márkaválasztás, illetve a márkaelkerülés vizsgálatánál.

A márkaelkerülés tipizálások sorában a harmadik kategória a morális vagy ideológiai okok miatt történő márkaelutasítás (moral avoidance), amelynek alapja lehet többek között a vállalati felelösségvállalás hiánya, származási ország hatása vagy hatalmi egyenlötlenség, vagyis a márka/ vállalkozás és a fogyasztó ereje közti kiegyensúlyozatlanság (Lee et al. 2009).

A negyedik fö kategória a márkaelkerülés motivációi között a feltételezett értéktelenség miatti elkerülés. A fogyasztó még mielőtt kipróbálná az adott márkát már elutasítja, mert rossznak ítéli meg, például a csomagolása miatt vagy mert egy új márkáról van szó és bizalmatlan vele szemben. Az a minőség, amit az adott árért kap, nem éri meg neki. Egy előzetes értékítélet végez a fogyasztó, amely alapján ő úgy dönt, hogy ki se próbálja, mert az nem felel meg az elvárásainak. A feltételezett értéktelenség miatti márkakelkerülés akkor valósul meg, amikor a márka ára nem elfogadható a belőle származó előnyökhöz képest (Lee et al. 2009b). A fogyasztók kerülhetik azokat a márkákat, amelyek alacsony minőséget tükröznek és ebből kifolyólag értékhiányosak (Lee et al. 2009b). A Lee et al. (2009b) által megállapított négy kategóriát kibővítve, Knittel (2016) és szerzőtársai kimutatták a reklámok miatti márkaelkerülést. Tanulmányukban rávilágítanak arra, hogy a fogyasztó számára kevésbé szimpatikus tartalom vagy reklámüzenet, olyan hírességek szerepeltetése a reklámokban, akiket a fogyasztó nem kedvel, a zene, amely a fogyasztóban negatív érzelmeket kelt, valamint a reklámokra adott válasz, amely az üzenet befogadójának szubjektív értelmezésére utal, mind elöidézhetik a márkaelkerülést (Knittel 2016).

Az elözőekben említett márkaelkerülési motivációkra White et al. (2012) is rávilágított tanulmányukban. A szerzőhármas elgondolása alapján, egy márka lehet aktív vagy passzív okozója a márkaelkerülés jelenségnek. A márka aktív okozója a márkaelkerülésnek abban az esetben, ha a fogyasztó etnikai, vagy bármilyen más jellegü diszkriminációt érzékel, esetleg úgy gondolja, hogy a vállalkozás bizonyos társadalmi vagy gazdasági problémák okozója. Az előzőkkel ellentétben White et al. (2012) szerint a márka passzív okozója is lehet a márkaelkerülésnek. Az egyén jellemzően valamilyen, a múltban történt eseményhez kapcsolja a márkát, amelyhez kapcsolódóan rossz emléke van. A fogyasztók azáltal, hogy elutasítják azokat a márkákat, amelyekhez negatív érzelmek és rossz emlékek társulnak, egy nem kívánatos asszociációt próbálnak elkerülni. Ebben az esetben jellemzően az egyénnek mélyen gyökerező negatív élményei vannak a márkával kapcsolatban. Megjegyzendő ezek a negatív élmények lehetnek teljesen függetlenek a márka teljesítményétől például az egyén életében negatív szerepet betöltő személy kedvelte ezt a márkát White et al. (2012).

A fentiekben bemutatott megállapítások jól mutatják, hogy a márkaelkerülés mögött igen változatos okok húzódhatnak meg, amelyeknél jelentős szerepe van a társas interakcióknak, a fogyasztó szubjektív értelmezésének és a régi negatív élményeknek. Továbbá a memória fontossága is megjelenik, hiszen egy-egy negatív élmény vagy tapasztalat bizonyos esetekben hosszútávú hatásként mutatkozik meg a márkaválasztásban.

\section{MÓDSZERTAN METHODOLOGY}

A kutatással a célom az volt, hogy megvizsgáljam a nemzetközi szakirodalomban ismert márkaelkerülési motivációkat beazonosíthatóak-e hazai környezetben. Azt kívántam feltárni, milyen magatartatásbeli és érzelmi megnyilvánulások mentén ragadható meg a márkával szembeni negatív viszonyulás. A márkaviszony témaköre egy erősen érzelem vezérelt terület, így mélyreható, feltáró jellegü vizsgálatot igényel, nem véletlen, hogy a téma meghatározó kutatói (Aaker 1997, Fournier 1998, Aggarwal 2004, Lee et al. 2009) szintén a kvalitatív módszert alkalmazták. A márkaelkerülés motivációinak feltárásához két lépcsőben folytattam vizsgálatokat. A korábbiakban két fókuszcsoportos kutatást végeztem, összesen 15 fö részvételével egy szükebb -, de a világon leggyakrabban kutatott (Rapp \& Hill 2015) - célcsoport, az egyetemisták körében. Ezt követően három mélyinterjút készítettem, 28-38 éves korosztály körében. A két különböző célcsoport választással az volt a célom, hogy változatosabb képet kapjak a márkaelkerülés motivációiról. Mind a mélyinterjúk, mind a fókuszcsoportos megkérdezés félig strukturált keretek között zajlott, amellyel azt szerettem volna elérni, hogy minél inkább kibontakozzanak a résztvevők. A mélyinterjúk és a fókuszcsoportos megkérdezés módszertana némileg eltért egymástól. A két kuta- 
tási módszertan sajátosságaiból adódóan eszközöltem ezeket a kisebb változtatásokat. A fókuszcsoportos kutatás során a megkérdezetteknek meg kellett nevezniük egy olyan márkát, amelyet elutasítanak, továbbá a termékkategóriát, és egy érzést az elutasított márkával szemben. A mélyinterjúk keretében megkértem a résztvevőket, hogy soroljanak fel minimum három, maximum öt olyan márkát, amelyeket ugyan meg tudnának vásárolni, mert az anyagi lehetőségeik megengedik, továbbá hozzáférnek a márkához az üzletben, de szándékosan nem vásárolják meg, sőt ha nincs más az üzletben, akkor inkább nem vásárolnak semmit abban a termékkategóriában, ha csak azaz egy márka kapható, amit nem kedvelnek. A résztvevők a mélyinterjúk keretében szabadon választhattak három vagy öt termék vagy szolgáltatásmárkát, annyi feltétel volt, hogy egy termékkategóriából csak egy márkát választhattak. Mind a fókuszcsoportos megkérdezés, mind a mélyinterjúk keretében a célom az volt, hogy feltárjam az egyének az általános attitüdjét, tapasztalatait és érzelmeit az elkerült márkával kapcsolatban. Egy szürőkérdést is beépítettem az interjúkba, annak érdekében, hogy elkerüljem azt az esetet, amikor egy adott termékkategória általános elutasításáról van szó, ugyanis ebben az esetben nem megoldható a márkaelutasítás vizsgálata. Ezeket az eseteket kivettem az elemzésből.

\section{EREDMÉNYEK RESULTS}

Általánosságban elmondható, hogy mind a mélyinterjúkban, mind a fókuszcsoportban résztvevők nehezen tudtak a témáról beszélni, valamint néha túl személyesnek érezték az általam feltett kérdéseket. Elutasított márkák közül jellemzően ruházati cikkek, okostelefonok, ételek, italok, kozmetikumok és autó márkák kerültek említésre. Az élelmiszer kategóriában voltak olyan esetek, amikor magát a terméket utasítják el, mert allergiás az adott összetevőre, így nem vásárolja meg vagy nem illik bele abba az életvitelbe, amit ő próbál tartani. Ebben az esetben ezt a márkát figyelmen kívül hagytam az elemzés során. A következőkben összevontan bemutatásra kerülnek a primer kutatásaim eredményei, amelyek alapján feltárható a vizsgálatban részt vevő személyek márkaelkerülésének motivációi. Az eredményeket az alábbi 6 megállapítás mentén $(\mathrm{M})$ összegzem.

M1 megállapitás: Az elkerült márkával kapcsolatban a kutatásban résztvevők többségének van valamilyen elözetes tapasztalata.
A résztvevők egy márka kivételével olyan márkát említettek, amelyet már használtak, függetlenül attól, hogy a terméket ők vásárolták-e meg vagy ajándékba kapták. Ebben az esetben a szakirodalomban vizsgált termékteljesítménnyel való elégedetlenség jelent meg motivációs tényezőként az elkerülés során. A megkérdezettek által elvárt teljesítmény nem egyezett meg az észlelt, a termék valós teljesítményével. Bizonyos esetekben a márka iránti ellenérzésük negatív szájreklámban is megnyilvánult.

„Régen vettem és szerettem ezt a márkát, de most már nem tudok venni magamnak ruhát. A minőséggel, a stílussal és a mérettel is vannak most már problémák. Egyszerüen be sem megyek az üzletbe már." (Viki)

„Igen, ajándéka kaptam, de magamnak nem vennék ott ruhát." (Adri)

„A régi telefonban nagyot csalódtam és azóta mindenkinek elmondom, hogy ilyet ne vegyen." (Anna)

Fontos megállapítás, hogy a márkaelkerülést már az is előidézheti, ha csak közvetett kapcsolat jön létre az egyén és a márka között, azaz ebben az esetben nem a szó szoros értelmében vett márkahasználat idézi elő a márkaelkerülést.

„Csak utasként ültem a kocsiban.” (Linda) „Nem vezettem még ilyen típusú autót, de ültem már ilyenben. Nem volt jó kényelmi szempontból és nem volt meg a biztonságérzésem sem." (Viki)

A fenti megállapítások a szakirodalomból ismert tapasztalaton alapuló márkaelkerülés kategóriájába tartoznak, hiszen a márkaelkerülés oka valamilyen márkával megélt korábbi tapasztalatra vagy tényleges használatra vezethető vissza.

M2: A márkaelkerülés kialakulásához nem szükséges tényleges fogyasztó-márka interakció.

Fontos megállapítás, hogy már a termék kipróbálása előtt is kialakulhat a fogyasztóban a márka iránti ellenszenv. Ennek hátterében a fogyasztó fejében lévő márka imázs, illetve a márka tipikus használójáról kialakult kép húzódik meg.

„Nekem személy szerint nem volt még ilyen ruhám, de nagyon rossz a minösége és csak azért drága, mert hírességek hordják. Engem ez rettentöen boszszant." (Brigi)

„Nem használtam és nem is akarom.” (Linda) 
M3: Az egyén identitása és a márka által sugallt kép közötti inkongruencia elöidézheti a márkaelkerülést.

Jellemzően a választott márkával szembeni negatív megnyilvánulás abból fakadt, hogy a megkérdezetteknek nem szimpatikus a márka által sugallt imázs, sőt bizonyos esetekben visszataszító számukra a márka, illetve nem tudnak és nem is szeretnének a márka tipikus használójával azonosulni.

„,Maga a termék jó, de a felhasználói miatt nem szeretem." (Csaba)

„Nem akarok egy ilyen tömegtermék fogyasztójává válni, mert akik ezt a márkát használják kispolgári, nagyon unalmas, szürke emberek." (Linda)

„Nagyon amerikai, ott van mindenhol agymosás szerüen van benne a köztudatban. Olyan mintha rád akarnák erőszakolni, söt ha nincs Iphone-od úgy érzed, hogy te már egy senki vagy. Nem szeretnék ebbe a közegbe tartozni." (Adri)

Márkaelutasítás mögötti motivációs tényezőként jelent meg a divatot követőktől való elkülönülés iránti vágy. A megkérdezettek nem szeretnék a fogyasztásukkal a tömeget követni.

„,Annyira felkapott, annyira nagy népszerüségnek örvend, mindenki már ilyet akar venni. Én, ha lenne még jó nyomógombos telefon esküszöm azt használnám." (Péter)

Fontos megállapítás, hogy a megkérdezettek ismernek olyan személyeket, akik vásárolják az általuk elkerült márkákat. Többségében a megkérdezettek közvetlen környezetében lévő személyek (családtagok, barátok) azok, akik használják az említett márkát.

„Akiket ismerek, ök önbizalomhiányban szenvednek. Mutatni akarnak valamit kifele, ki szeretnének tünni a tömegböl, haveri a kapcsolat velük." (Adri) „, Sokan használják a környezetemben. Lépést akarnak tartani a trendekkel, érdeklik öket az új dolgok, nem akarnak lemaradni az új dolgokról. Nem itélem el öket." (Viki)

„A testvérem, de azért veszi ezt, mert jobban szereti az izét." (Linda)

M4: Amennyiben a márkák elutasítása érzelmi alapon történik, akkor az intenzíven mutatkozik meg.

Az érzelmi alapon történő márkaelutasítás intenzíven mutatkozott meg, amelyhez negatív személyes történet is társult. A résztvevők a szóban forgó márkával kapcsolatban taszításról, enyhe undorról, szorongásról és frusztrációról számoltak be.

„Amikor gyerek voltam, akkor elsősorban kelet-európai országokba lehetett utazni és nagyon sokat kellett várni a határon és mindig ezek az autók álltak a határon. Maradt egy olyan emlékem, hogy a határellenörzésektöl akkoriban félni kellett, mert kifele féltünk, hogy mi van, ha elveszik azt a pénzt, amit viszünk magunkkal. -Hazafele féltünk, hogy mi lesz, ha elveszik azt, amit egyébként vásároltunk magunknak. Mindig Skodák álltak körülöttünk. Egy szorongás érzés társul a Skodához, amitöl szeretném magam távol tartani." (Linda)

„Borzasztó, utálom, lefagy, akad, lemerül gyorsan - lehet csak ez a modell, de akit ismerek és ezt a modellt használja az utálja, kezelhetetlen a telefon." (Viki)

A fenti vélemények tükrében megállapítható, hogy a márkaelkerülésnek különböző fokozatai lehetnek, amelyek forrása lehet a gyenge minőséggel való elégedetlenség vagy egy korábban átélt negatív személyes tapasztalat.

M5: A reklámok meghatározóak a márkaelkerülés során.

Megfigyelhető volt, hogy néhány esetben a megkérdezettek alapvetően elégedettek voltak a termékkel, de a reklámok miatt nem vásárolják meg mégsem az adott márkát. Megjegyzendő azonban, hogy ebben az esetben nem beszélhetünk teljes mértékben elutasításról, hiszen, ha a megkérdezettnek nincs választási lehetősége, akkor megvenné a márkát. Elsősorban a reklámok tartalma, illetve az általuk közölt üzenet miatt elutasították el az interjúalanyok az általuk megnevezett márkát.

„Biztos meg nem venném a Pepsit, nem tetszenek a reklámok, legfeljebb kényszerböl, ha nincs más az étteremben. Le van maradva és nem néz körül, hogy mi zajlik a világban. Ízléstelen amit a Pepsi csinál abban a világban, amiben élünk. Nem ilyen irányból kellene megközelíteni a reklámokat, ennél társadalomtudatosabbaknak kellene lenniük. Semmit nem hall a Pepsi ami körülöttük történik”" (Linda) „Kicsit alattomos, mert azt kommunikálja, hogy ez milyen jó dolog, milyen jó, hogy mindenhol ott van, miközben a termék egy szemét. A reklámokból nem ez jön le, és még a gyerekek is meg tudják venni kevés zsebpénzből is. " (Adri) 
M6: Az elkerült márka megvásárlása a jövőben megtörténhet.

Az interjú alanyok néhány márka kivételével a legtöbb esetben nem zárkóznak el az említett márkák megvásárlása elöl. Fontos azonban megjegyezni, hogy nem saját használatra vennék meg a terméket. Saját használatara csak abban az esetben vásárolnák meg, ha megszünne az a gátló tényező, amely miatt jelenleg elkerülik a márkát vagy, ha egy kényszer szülte szituációban lennének.

\section{„Magamnak biztos nem vennék ilyet, maximum} ajándékba." (Adri)

„,Kényszerböl venném meg, ha nincs más az étteremben." (Linda)

„Igen, ha lesz a méretében valami, ami tetszik neki."(Viki)

A fenti megállapítások vegyes képet mutatnak a márkaelkerülés motivációiról. Az eredmények alapján jellemzően a márkaelutasítás mögött egy korábbi, a márkahasználattal kapcsolatos negatív tapasztalat húzódik meg. Fontos megállapítás azonban, hogy már a termék kipróbálása elött is kialakulhat a fogyasztóban a márka iránti ellenszenv, melynek hátterében a fogyasztó fejében lévő márka imázs, illetve a márka tipikus használójáról lévő kép húzódik meg. Fontos leszögezni, hogy mind a minta nagysága, mind az összetétele az eredményeket erősen korlátozza, így az eredmények csak a kutatásban résztvevő személyek véleményét mutatják be, nem tekinthetőek általános érvényünek.

\section{KÖVETKEZTETÉSEK, JAVASLATOK CONCLUSION, RECOMMENDATION}

Annak ellenére, hogy a vizsgálatot szúk mintán végeztem az eredmények jól mutatják, hogy van relevanciája a márkaelkerülés vizsgálatának. A kvalitatív kutatás során feltárt motivációk több ponton megegyeznek a szakirodalmi áttekintés során bemutatott motivációkkal. A márkaelkerülés motivációinak tipizálásából a kutatásomból hangsúlyosan az önkifejezésen alapuló márkaelkerülés és a tapasztalaton alapuló márkaelkerülés jelenik meg. Kevésbé hangsúlyosan a reklámok miatti márkaelkerülés. Kiemelendő még, hogy az eredmények alapján a legtöbb esetben nem zárkóznak el az említett márkák megvásárlása elől a kutatásban résztvevő személyek, de az elkerült márkát nem saját használatra vennék meg, illetve csak abban az esetben vásárolnák meg saját használatara, ha meg- szünne az a gátló tényező, amely miatt nem veszi meg. Túlnyomó többségében a márkaelkerülés egy korábbi negatív tapasztalon alapul, amely többségen márkahasználathoz köthető és kisebb mértékben valamilyen negatív élményhez. Az érzelmek megjelenése kevésbé volt hangsúlyos egy-egy elkerült márka kapcsán, de azokban az esetekben amikor megjelent, akkor intenzíven mutatkozott meg.

A márkaelkerülés vizsgálatának gyakorlati hasznosíthatósága márkamenedzsment szempontból kiemelt jelentőséggel bír. Abban az esetben, ha a fogyasztók negatívan vélekednek egy márkáról, akkor marketing szempontból érdemes egy másik területre koncentrálni. A tapasztalaton alapuló márkaelkerülés hatékonyan kezelhetö többek között a megfelelő reklamációkezelés kidolgozásával, vagy megoldás lehet még a márka újrapozícionálása is. Mindezeken túl pozitív irányba mozdíthatja el a márkával szembeni negatív attitúdöt, ha a márka vagy vállalat a társadalmi felelősség vállalás érdekében eszközöl valamilyen intézkedést, amelynek sajtóvisszhangot ad. A tapasztalaton alapuló márkaelkerülés esetén azonban a hosszútávú megoldás az lenne, ha a vállalkozás a termékminőségen javítana.

\section{ÖSSZEFOGLALÁS SUMMARY}

Annak megértése, hogy a fogyasztó, hogyan észleli a márka által nyújtott előnyöket, hogyan értelmezi a márka üzenetét illetve a márkaszemélyiséget, hozzájárul ahhoz, hogy miként alakul és müködik a fogyasztó-márka kapcsolat. A tanulmánnyal a negatív irányú fogyasztó-márka kapcsolat mozgatórugóira kívántam rávilágítani, illetve azoknak a motivációknak a feltárására törekedtem, amelyek a márkaelkerülésben szerepet játszhatnak. Az eredmények rávilágítanak arra, hogy különbözö, szubjektív okok húzódnak meg a márkaelkerülés mögött, illetve kirajzolódott, hogy a márkaelkerülés különböző mértékben jelenhet meg.

A márkaelkerülés során a negatív érzelmek és a márkával összefüggő rossz tapasztalatok meghatározóak lehetnek, tehát érdemes feltárni, hogy milyen és mekkora szerepe van ezeknek a tényezőknek a márkával szembeni negatív viszonyulás kialakulásban, illetve fennmaradásában. $\mathrm{Az}$ a megállapítás, hogy a legtöbb esetben az elkerült márkát megvásárolnák a kutatásban résztvevők - még ha nem is saját használatra - további kutatási kérdéseket vet fel. Jövőbeli kutatási irány lehet még annak a vizsgálata, hogy egy olyan márkát, amit valamilyen okból kifolyólag elke- 
rül a fogyasztó egy influencer rá tud-e beszélni arra, hogy megvegyen. Továbbá a fogyasztómárka kapcsolatok dinamikájára alapozva érdekes vizsgálati terület lehet, hogy milyen márkákkal kapcsolatban változott a fogyasztók véleménye és minek a hatására. Ehhez szorosan kapcsolódik az a kérdéskör, hogy van-e olyan márka a fogyasztó életében, amelyről korábban kijelentették, hogy soha nem vennék meg, de aztán mégis megvették. Jelen tanulmány a márkaelkerülés kérdéskörét kvalitatív módon vizsgálta, de a jövőben kvantitatív kutatásokat is érdemes lenne végezni ezen a területen.

\section{HIVATKOZÁSOK REFERENCES}

Aaker, J. L. (1997), 'Dimension of brand personality", Journal of Marketing Research, 34, 347 356. DOI: $10.1177 / 002224379703400304$

Aggarwal, P. (2004), "The Effects of Brand Relationship Norma on Consumer Attitudes and Behavior", Journal of Consumer Research, 31(June), 87-101. DOI: 10.1086/383426

Belk, R.W. (1988), "Possessions and the Extended Self', Journal of Consumer Research, 15(September), 139-168. DOI: 10.1086/209154

Fournier, S. (1998), "Consumers and Their Brands: Developing Relationship Theory in Consumer Research", Journal of Consumer Research, 24 343-372. DOI: $10.1086 / 209515$

Grzeskowiak, S. and Sirgy, J.M. (2007), ”Consumer Well-Being (CWB): The Effects of Self-Image Congruence, Brand Community Belongingness, Brand Loyalty, and Consumption Recency", Applied Research Quality Life, 2(4), 289-304. DOI: $10.1007 / \mathrm{s} 11482-008-9043-9$

Grubb, E.L. and Grathwohl, H. L. (1967), "Consumer Self-Concept, Symbolism and Market Behavior: A Theoretical Approach", Journal of Marketing, 31(October), 22-27. DOI: 10.2307/1249461

Gyulavári T., Malota E. (2014), „Az énkép-illeszkedés elmélet szerepe a fogyasztók turisztikai desztinációértékelésében", Marketing \& Management, 48(3), 5-14

Hogg, M. K. (1998), ”Anti-Constellations: Exploring the Impact of Negation on Consumption" Journal of Marketing Management, 14, 133158. DOI: 10.1362/026725798784959354

Holt, D. B. (1998), "Does Cultural Capital Structure American Consumption?", Journal of Consumer Research, 25(1), 1 -25. DOI: $10.1086 / 209523$
Iyer R .- James, A. and Muncy J. A. (2009), 'Purpose and object of anti-consumption", Journal of Business Research, 62, 160-168. DOI: 10.1016/j.jbusres.2008.01.023

Kovács K. (2009), „A divatterjedés és a divattermékek fogyasztását befolyásoló tényezők empirikus vizsgálata a hazai fiatalok körében", Marketing\&Menedzsment, 43(1), 62-71

Knittel, Z., Beurer, K. and Berndt, A. (2016), "Brand avoidance among Generation Y consumers", Qualitative Market Research: An International Journal, 19(1), 27 - 43. DOI: 10.1108/QMR-03-2015-0019

Kressman, F., Sirgy, M.J., Herrmann, A., Huber, F., Huber, S. and Lee, D.J. (2006), 'Direct and indirect effects of self-image congruence on brand loyalty", Journal of Business Research, 59(8), 955-964. DOI: 10.1016/j.jbusres.2006.06.001

Lee, M. S. W., Conroy, D. and Motion, J. (2009a), "Brand Avoidance: a Negative Promises Perspective, Advances in Consumer Research", Association for Consumer Research, 36, 421429

Lee, M. S. W., Motion, J. and Conroy, D. (2009b), "Anti-consumption and brand avoidance", Journal of Business Research, 62, 169-180. DOI: 10.1016/j.jbusres.2008.01.024

Levy, S. J. (1959), "Symbols for sale", Harvard Business Review, 37(4), 117-124

Nenycz-Thiel, M. and Romaniuk, J. (2011), "The Nature and Incidence of Private Label Rejection", Australasian Marketing Journal, 19, 93-99. DOI: 10.1016/j.ausmj.2011.02.001

Rapp, J. M., Hill, R. P. (2015), ’Lordy, Lordy, Look Who's 40!" The Journal of Consumer Research Reaches a Milestone", Journal of Consumer Research, 42(1), 19-29. DOI: 10.1093/jcr/ ucv011

Sirgy, M. J. (1982), "Self-concept in consumer behavior: A critical review", Journal of consumer research, 9, 287-301. DOI: $10.1086 / 208924$

Szántó Sz. (2003), Cikkek a fogyasztói magatartás témaköréből, BGF-KKFK, Nemzetközi Marketing Tanszék, Budapest

White, A., Breazeale, M. and Webster, C. (2012), "Motivations for the brand avoidance relationship", In Fournier, S., Breazeale, M., Fetscherin, M. (eds), Consumer-Brand Relationships Theory and Practice. Routledge, London and New York, 57-73 
Tamasits Dóra, PhD hallgató tamasitsdora@gmail.com

Szegedi Tudományegyetem

\section{Motivations of the brand avoidance}

\section{THE AIMS OF THE PAPER}

Present study demonstrates the widely known and debated consumer-brand relationship, particularly focusing on the phenomenon of brand avoidance. However, the traditional consumer researches focus predominantly on the consumer loyalty, the examination of negative consumer-brand relationship is actual. The extant literature on the field brand avoidance is scarce.

\section{METHODOLOGY}

The research is based on a primary research. Three depth-interviews and two focus group researches were carried out in autumn, 2018 in order to find out the motivations of brand avoidance.

\section{MOST IMPORTANT RESULTS}

Based on previous supposition the motivation of the brand avoidance are caused by symbolic consumption (self-expression) which means consumers avoid certain brand because of the brand personality, brand image and the typical brand user. Partly, the results of the qualitative research certifies this supposition, but the functional factors and the message of the advertisement are important elements for the brand avoidance as well.

\section{RECOMMENDATIONS}

It is important to discover which factors are the those key elements that cause the brand avoidance. Firstly, if we know these factors we can prevent for more losing consumers. Secondly, nowadays the opinion of consumers is critic for the brand successful, because the negative word of mouth (WOM) might be harmful.

Keywords: consumer-brand relationship, brand avoidance, anti-consumption 